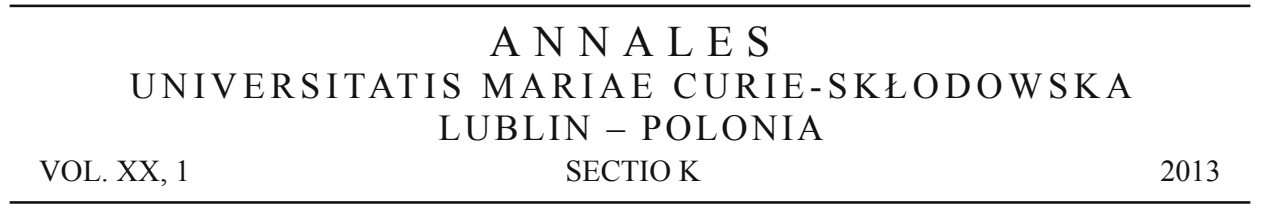

Faculty of Political Science, Maria Curie-Skłodowska University, Lublin - Poland

MARIA MARCZEWSKA-RYTKO

\title{
Direct democracy at the national level in Poland. The case of referendum
}

\begin{abstract}
The aim of the article is to analyze a referendum as the main institution characteristic of direct democracy at the national level in Poland. The article consists of two parts. First of them is connected with direct democracy before 1989, and the second one after 1989. Direct democracy has never been or is particularly esteemed in Poland. The referendum of 30 June 1946 was essentially instrumental and the initiators utilized it as a way to hold power and legitimize it. High expectations were placed on the transformation period after 1989. The referendum of 30 June 1946 was essentially instrumental. The initiators utilized it as a way to hold power and legitimize it. The next referendum of 29 November 1987 also became part of the negative practice of politicizing this instrument of direct democracy. High expectations were placed on the transformation period after 1989. The President's referendum bill of November 1995 concerning the general granting of property rights to citizens was passed. This motion was approved because it was initiated by the President and then supported by the motion of a group of the SLD Deputies concerning the sharing out of State property. Under such circumstances those submitting the motion had a guaranteed majority necessary for taking an appropriate resolution. It became the grounds for the referendum which was held on 18 February 1996. The next referendum was the Constitution-approving one of 25 May 1997. The political scene was clearly divided into the supporters and opponents of the new Constitution. On 17 April 2003 the Sejm passed a resolution on ordering a nationwide referendum concerning Poland's membership of the European Union.
\end{abstract}

Key words: direct democracy, Poland, referendum, political participation. 


\section{INTRODUCTION}

Direct democracy is the alternative system of government in relation to indirect (liberal) democracy. Among the institutions characteristic of this form of democracy, the controlling power is vested in the popular (or people's) assembly and the referendum (people's vote), while the people's initiative, the people's veto and consultations are of procedural character [Marczewska-Rytko 2001]. Direct democracy has never been or is particularly esteemed in Poland. In Poland, like all over the world, the most frequent form of direct democracy is currently a referendum. The aim of the article is to analyze this institution characteristic of direct democracy at the national level in Poland. The article consists of two parts. First of them is connected with direct democracy before 1989, and the second one after 1989.

\section{DIRECT DEMOCRACY BEFORE 1989}

Reference to a referendum does not have a long tradition in Poland: such a solution was not known during the interwar period, nor was it stipulated in the provisions of the 1952 Constitution [Jabłoński 2001]. In practice, emphasis was placed on the institution of social consultations [Grodzicki 1987]. The referendum of 30 June 1946 was held on the basis of ad hoc statutory regulations and it was meant to legitimize the State authority [Ustawa z dnia 27 kwietnia 1946; Ustawa z dnia 28 kwietnia 1946; Referendum z 30 czerwca 1946; Jaskiernia 1987; Kersten 1990]. It was essentially instrumental and its initiators were by no means interested in creating a situation where the people as the sovereign would express their opinion. As Andrzej Paczkowski stated "its (referendum's) feature (albeit informal) was that it was held instead of the election to the Legislative Sejm (Parliament). Strictly speaking, it was a convenient pretext for postponing the elections until at least half a year" [Paczkowski 1995: 67; Paczkowski 1999]. The initiators utilized the referendum or, to be precise, its rigged results, as a way to hold power and legitimize it. In this sense we can agree with Paczkowski when he insisted that "the first attempt in Poland's history to introduce the institution of the referendum into the political system did not bring credit to democracy" [Paczkowski 1995: 76]. At the same time, this is an argument in support of the proposition put forward in this study that the use of the institution of the referendum need not necessarily be identified with direct democracy because sometimes it is a departure from democratic rules [Marczak 1986]. The positive side, I believe, is that this starts a discussion under the Polish circumstances on the institution of the referendum since at that time different points of view on the role of the referendum and its connections with, for example, the institution of the plebiscite were voiced.

The next referendum of 29 November 1987 also became part of the negative practice of politicizing this instrument of direct democracy [Kuciński 1989: 47-56]. The referendum was prompted by the regulations in the documents issued before the $19^{\text {th }}$ 
Congress of the Polish United Workers' Party (PZPR). During the sessions of the $1^{\text {st }}$ Congress of the Patriotic Movement for National Rebirth (PRON) the delegates supported the law on social consultations and the referendum. As a result, a group of 115 Deputies (Members of Parliament) submitted a bill on social consultations and referendum, which was met with many doubts and controversies. A significant role, I believe, was played by the fear of passing many empowerments to citizens. It was concluded that for the referendum to have the binding power, Poland's Constitution would have to be amended, which showed a change in the status of the institution of the referendum as compared with 1946 and its established position in the supreme law, i.e. the Constitution.

On 6 May 1987 the amending of the Constitution and the law on social consultations and referendum was passed [Ustawa $\mathrm{z}$ dnia 6 maja 1987]. The Constitution stipulated that the people's power could also be expressed by means of a referendum. In this way the hierarchy of particular powers was indicated: the power exercised by the elected representatives was supplemented by reference to the sovereign (i.e. the people) in respect of matters of particular importance. Furthermore, this direct reference to the sovereign was possible only on the motion of a higher authority in hierarchy, i.e. representatives holding parliamentary seats and in the people's councils.

The Sejm opted for referendums and consultations at the national and local levels, which was expressed in Article 2 of the Law. It was emphasized that the subject of social consultations or a referendum should be matters of particularly great importance for the development of the country and for the citizens' interests. Final decisions concerning the assessment of the significance of a matter were to belong to the body that would initiate a consultation or a referendum. We should add that some issues, for example those connected with the State's defense or security, were excluded, ex officio as it were, as the subjects of consultations and referendums. As far as the question of who had the right to take part in a referendum was concerned, citizens who stayed in the country and had voting rights were entitled to participate in a nationwide referendum; as regards referendums at the local level, those entitled were the citizens who were registered for permanent residence in the area where a referendum was held. In both cases, we can speak of significant restrictions. Moreover, a motion for consultations or a referendum was not binding. This means that it could be accepted but it did not have to. Observe also another aspect of the adopted solution. The provisions stipulated that a very high threshold had to be achieved so that the referendum result was binding. It was decided that over half the number of those entitled to vote would have to support a solution or decision - as stipulated in Article 19. This provision raised justified doubts because in practice it was very difficult to obey. Consequently, questions arise whether this was to be merely a formal provision or the instrument genuinely enabling citizens to express their views and thereby settle problems that were important from the social point of view. Which was regarded as more important: the fear of solutions/decisions taken as a result of voting in a referendum or the fairly substantial funds spent on the organization of this form of democracy? I am convinced that the authorities at that time were afraid to pass 
this important instrument to the citizens themselves, and if they agreed to do so, they sought to restrict their (citizens') right with far-reaching provisions. It also appears that rather than being afraid to spend so much on the organization of the referendum, the authorities feared the results of the citizens having supported a particular solution. This is shown, for example, by the referendum results of 29 November 1987. It was a referendum initiated in accordance to the provisions in question.

As with the 1946 referendum, this one was also initiated top-down, its main goal being to obtain the citizens' consent to the policies of the ruling government and thereby legitimate the authorities. The resolution adopted by the Sejm read that the subject of the planned referendum would be the matters of reforming the State and the economy. The subject was expressed in two questions: (1) Do you support the full implementation of the program, presented to the Sejm, for radical economic recovery aimed at distinctly improving living conditions of the society, on the understanding that this would require a difficult two-to-three-year period of rapid changes? (2) Do you support the Polish model for democratizing political life, aimed at strengthening self-government, extending the rights of citizens and increasing their participation in running of the country?

It appears that the initiators of the referendum were not sure of the adequacy of the questions in relation to the actual subject of the referendum because explanations were additionally published in the press. What is more, these explanations left much to be desired in respect of their informative clarity and transparency [Jaskiernia 1995]. The voting results did not exceed the required threshold on both counts. Each question was answered by less than half the number of those having the right to vote. Consequently, the results obtained could not be recognized as binding. Nevertheless, as the society we learned an important lesson of the practical application of this form of democracy. First, one should not build surrealistic constructions that can hardly be realized in practice. The days of hundred percent (or nearly hundred percent) participation in voting are probably gone. Therefore, one should take into account the actual attendance and potentially possible under the most favorable conditions, when setting the threshold for the binding results. Second, the referendum should not be an institution the ordering of which remains exclusively in the hands of those governing. The fundamental values that are inherent in this form of democracy require, in a way, that it be applied even against the will of the ruling government. The problems discussed, concerning the adopted solutions and the two referendums that were held, seem to explicitly point to the importance of the political context. When there is a deficit of democracy it is difficult to expect that, without significant constraints, such political system solutions would be allowed as would evidently tie the hands of the ruling authorities. For that reason such high expectations were placed on the transformation period after 1989. After all, the changes taking place meant the society's victory. Were these expectations fulfilled? 


\section{DIRECT DEMOCRACY AFTER 1989}

The period from 1989 to 1997 can be termed political system transformation. Its culmination was the adoption of the new Constitution. In this period we can speak of the absence of uniform constitutional regulations. In December 1989 a law was adopted on the amendment of the Constitution, which supported the sovereignty of the nation [Kruk 1998]. This did not carry with it an explicit consent to enabling the nation-sovereign to express their views on many vital issues. The Constitutional Act of 23 April 1992 on the Mode of Drafting and Passing the Constitution of the Republic of Poland recognized that the Constitution would be adopted by the nation as a result of voting in the constitutional referendum [Ustawa konstytucyjna $\mathrm{z}$ dnia 23 kwietnia 1992]. The referendum would be ordered by the President within fourteen days of the passing of the Constitution in the third reading. Each citizen of the Republic of Poland who had the voting rights was entitled to take part in the referendum. The referendum's result would be binding if the majority of voters would support the adoption of the Constitution. The Constitutional Act of 17 October 1992 on the Mutual Relationship between Legislative Power and Executive Power provided the possibility of recourse to the institution of the referendum in respect of matters of special importance to the State [Ustawa konstytucyjna $\mathrm{z}$ dnia 17 października 1992]. The right to order a referendum is exercised by the Sejm (as a result of the resolution passed by an absolute majority of votes) or by the President with the Senate's consent by an absolute majority vote. The referendum would be binding if more than half the number of those having the right to vote participated in it. In accordance with the provisions of the Constitutional Act of 22 April 1994 on Amending the Constitutional Act on the Mode of Drafting and Passing the Constitution of the Republic of Poland, the principles on which the Constitution would be founded, could be put to a vote in a referendum [Ustawa konstytucyjna $\mathrm{z}$ dnia 22 kwietnia 1994]. The final version of the law on the referendum was passed by the Sejm on 29 June 1995 [Ustawa z dnia 29 czerwca 1995 r. o referendum]. Article 5 of the Law on the Referendum adopted a solution in the form of the popular (people's) initiative concerning the referendum. Detailed solutions on the matter are contained in para 6, which reads inter alia that the Sejm can decide to put a specific matter to a referendum on the initiative of a group of citizens who have obtained support of their motion by at least 500,000 persons who have the right to vote in the parliamentary elections. A referendum on the initiative of group of citizens cannot concern the State's expenditure and revenue, or defense, or amnesty.

In the current Constitution of 1997 the institution of the referendum is provided for in Chapter Four, which deals with legislative power [Konstytucja Rzeczypospolitej Polskiej z dnia 2 kwietnia 1997]1. This might suggest a relationship between making laws and this institution. A referendum is an alternative procedure to expressing con-

${ }^{1}$ Compare also: M. Jabłoński, Wynik referendum a zasada dyskontynuacji prac Sejmu, "Przegląd Prawa i Administracji” 1998, no. 41, pp. 97-115. 
sent to ratify an international agreement and serves to adopt a law on the amendment of the Constitution. A nationwide referendum is treated as an exceptional procedure listed after the principles of operation of the Sejm and Senate. The right to order a referendum belongs only to the Sejm and to the President acting with the consent of the Senate. Its practical implementation appears therefore to be very unlikely because it is difficult to gain a broad political consensus, which is necessary when a resolution to hold a referendum is taken by an absolute majority vote in the presence of at least half the statutory number of Deputies. That is why it is more likely that the use of this institution at the nationwide level will be exceptional; it will serve to confirm the appropriate social and political support rather than to decide on matters of particular importance to the State. Chapter Four of the Constitution also contains the institution of the people's initiative. Article 118 stipulates that "The right to introduce legislation shall also belong to a group of at least 100,000 citizens having the right to vote in elections to the Sejm". Constraints on the people's initiative are specified in two articles of the Constitution. Under Article 221 "The right to introduce legislation concerning a Budget, an interim budget, amendments to the Budget, a statute on the contracting of public debt, as well as a statute granting financial guarantees by the State, shall belong exclusively to the Council of Ministers". Article 235, para 1 stipulates that "A bill to amend the Constitution may be submitted by the following: at least one-fifth of the statutory number of Deputies; the Senate; or the President of the Republic".

The President's bill on nationwide referendums of 8 October 2002 anticipated the adjustment of the principles of and procedures for holding referendums at the nationwide level to the Constitution's provisions (three kinds: in respect of matters of particular importance to the State, expression of consent by the citizens to ratify an international agreement, and in the matter of approving the amendment of the Constitution) and to adapt the regulations on referendums to the statute "The Electoral Law to the Sejm and the Senate" [Winczorek 2002].

On 14 March 2003 the law on the nationwide referendum was adopted [Ustawa $\mathrm{z}$ dnia 14 marca $2003 \mathrm{r}$. o referendum] ${ }^{2}$, and an amendment to it in connection with the planned referendum for the EU entry [Ustawa z dnia 10 maja 2003]. Among essential regulations, worth noting is Article 5, under which one can vote only in person. The proposals that one could vote by proxy or via the Internet were therefore rejected. Article 7 admitted of the establishment of constituencies in student hostels or groups of student hostels if at least fifty persons having the right to vote in a referendum informed the university/college president in writing about the fact of staying in a hostel on the day of the referendum. A two-day referendum was allowed. The organs which would hold a referendum are the National Electoral Commission, electoral commissioners, and district commissions for referendum. Articles 11-16 specified the responsibilities of particular agencies for referendums. Chapter Three of the Law contains

2 Compare: P. Uziębło, Nowe regulacje prawne dotyczące referendum ogólnokrajowego w Polsce, http://pedrou.w.interia.pl/referendum.htm (10.10.2012). 
the requirements concerning the ballot paper, the manner of voting and the terms of validity of a vote. Chapter Four specifies the requirements related to the establishment of the results of voting and the result of a referendum. Chapter Five is concerned with the question of the validity of a referendum. Of significant importance is Chapter Six, which presents the rules of holding a referendum campaign and funding it. The next Chapters of the Referendum Law deal with the following problems: funding of a referendum by the State budget (Chapter Seven); a referendum in respect of matters of particular importance to the State (Chapter Eight); a referendum on the consent to ratify an international agreement (Chapter nine); a referendum to approve the amendment of the Constitution of the Republic of Poland (Chapter Ten); criminal provisions (Chapter Eleven); special provisions (Chapter Twelve); and amendments to the current provisions in force, as well as final and transitional provisions (Chapter Thirteen). The amending of the Referendum Law aimed at enabling the public announcement of information on attendance while a referendum lasted. Article 63 stipulated that "the Sejm may decide to put a specified matter to a referendum on the initiative of citizens who can gain support for their motion by at least 500,000 persons having the right to vote in a referendum". A reservation was made, however, that a referendum on the citizens' initiative could not concern such matters as the State's expenditure and revenues (especially taxes and other public levies), State defense, and amnesty.

Let us now take a brief look at the practice of using referendums because the referendum seems to play the greatest role among the institutions of direct democracy in Poland. The first initiative by the Sejm Deputies - a draft resolution on nuclear energy - was not put to the vote. Another bill submitted by the Deputies concerning the election system, the structure of the Parliament and the model of Poland's political system did not win the required majority of votes. Interestingly enough, in the parliamentary discussion there were opinions showing the reluctance of many Deputies to "share their power". In 1991 three draft resolutions on holding a referendum were submitted. They concerned the following matters: the second chamber of the Parliament (no resolution was passed), on the admissibility of pregnancy abortion (this was the first, not examined, initiative on this matter), reprivatization and privatization of property (not examined). Observe that the draft resolutions on the admissibility of pregnancy termination were the most controversial, leading to tumultuous discussions. The draft resolution of March 1992 was rejected on the first reading. Eventually, in November1992 the Sejm rejected the bill on holding a referendum on that matter. The decisive role was played by the adverse attitude of the episcopate and the political parties which explicitly referred to the Church for support ${ }^{3}$. This was broadly discussed by Michał T. Staszewski [Staszewski 1995]. We should also compare the opinion expressed by Antoni Malinowski: "Thus, Poland did not utilize the

\footnotetext{
${ }^{3}$ The Episcopate also opposed the referendum on privatization, invoking the commandment "You shall not steal": "Nie kradnij”. Nie powinno być referendum. Episkopat o uwłaszczeniu i reprywatyzacji, "Gazeta Wyborcza", 10.03.2000, p. 5.
} 
experience of many Western democracies which used the referendum when deciding about problems of this kind. Therefore, despite the growing role of the referendum in present-day democratic countries, in our country the citizens were deprived of the opportunity to take advantage of this form of direct democracy and to decide on the important social problem. This can be interpreted as the fact that those governing regarded society as not mature enough to take decisions. This is a manifestation of restricting the sovereignty of the people" [Malinowski 1996:113]. That issue was returned to when submitting bills for referendums in other matters. For example, in September 1995 the question of admissibility of abortion was raised by the Women's Parliamentary Group, who tried to include it in the bill for a preliminary constitutional referendum, or in November that year when Unia Pracy (Union of Labor) Deputies submitted a bill which also comprised the issues concerning abortion (it was rejected by the Sejm). In 1997 the SLD (Democratic Left Alliance) Deputies put forwards a bill on this matter but it was turned down by the Sejm.

There were also other motions for referendums but they were not approved by the Sejm: a referendum on the general granting of property rights to citizens (the motion submitted by the President in October 1995); a referendum on reprivatization, on admissibility of tuition fees in public schools, on the system of local selfgovernment, as well as on the right to abort pregnancies (the motion submitted by Unia Pracy Deputies in November 1995); a referendum on the reform of division of and the political system of the territory of the Republic of Poland (the motion submitted by the PSL [Polish People's Party] in April 1998 r); a referendum on reprivatization (proposed by the PSL Deputies in September 1999); a referendum on privatization and reprivatization of forests (citizens' motion signed by 543,000 citizens, of January 2000); a referendum on consent to ratify Protocol No. 6 to the European Human Rights Convention (Deputies' motion of March 2000); a referendum on the scope, forms and costs of reprivatization of public property taken over by the State under the nationalization laws in 1944-1962 (citizens' motion signed by 571,000 people); a referendum on the preservation of national Polish treasures (the bill submitted by a group of LPR [League of Polish Families], Samoobrona [Self-Defense], PSL and Dom Ojczysty [Native Home] Deputies); a referendum on the Republic of Poland citizens' consent to sell land to foreigners (citizens' motion); a referendum on the opposition to selling Polish land to foreigners (LPR's bill of October 2002: 254 Deputies voted against); an urgent referendum on Poland's membership of the EU (LPR's motion: 328 Deputies voted against); a referendum on the line of reform of the health service (President Lech Kaczyński's bill of 2008: rejected by the Senate).

Observe that the President's referendum bill of November 1995 concerning the general granting of property rights to citizens was passed. The President proposed one question: are you for the general granting of property rights to citizens? This motion was approved because it was initiated by the President and then supported by the motion of a group of the SLD Deputies concerning the sharing out of State property. Under such circumstances those submitting the motion had a guaranteed 
majority necessary for taking an appropriate resolution. It became the grounds for the referendum which was held on 18 February 1996, concerning the use of State property. The complicated problems and the unclear wording of the questions were largely responsible for the fact that only thirty percent of society participated in the referendum [Frekwencja ponad 32 procent $]^{4}$. It should be pointed out that most of the mistakes committed during the earlier referendums also made themselves felt in this voting, which did not bring credit to its initiators.

The next referendum was the Constitution-approving one of 25 May 1997. The political scene was clearly divided into the supporters and opponents of the new Constitution. It should be reminded that the Electoral Action Solidarity [Akcja Wyborcza Solidarność (AWS)] and the Movement for Reconstruction of Poland [Ruch Odbudowy Polski (ROP)] took measures aimed at influencing the parliamentary majority - the Democratic Left Alliance [Sojusz Lewicy Demokratycznej] and the Polish People's Party [Polskie Stronnictwo Ludowe] so that this bloc included in the new Constitution the solutions contained in the citizens' draft Constitution [Mołdawa 1996; Projekty Konstytucji... 1997]. When this turned out to be unrealistic, the demand was advanced that the two drafts - the one passed by the National Assembly and the citizens' draft be voted on in a referendum, which was obviously inconsistent with the law on the procedure passing the Constitution. Consequently, the AWS and ROP called on the people to vote "no" in the referendum. The Constitution was ultimately adopted by a small majority vote. The attendance was $42.86 \%$ of those having the right to vote. $52.71 \%$ of voters were in favor of the Constitution, and $45.89 \%$ against $^{5}$. From the formal point of view this result was sufficient to adopt the Constitution. In practice, however, we can speak of many political and social embroilments [Gebethner 1997].

On 17 April 2003 the Sejm passed a resolution on ordering a nationwide referendum concerning Poland's membership of the European Union ${ }^{6}$. The resolution was adopted by the votes of 417 Deputies, with one vote against and two abstaining. The date of the referendum was set for 7 and 8 June 2003. The question asked in the referendum was: Do you consent to the Republic of Poland's entry into the

${ }^{4}$ Compare objections against a referendum in: Uchwała Sądu Najwyższego z dnia 15 kwietnia 1996 r. w sprawie ważności referendum o powszechnym uwłaszczeniu obywateli, Dziennik Ustaw 1996, nr 50, poz. 218 (the Supreme Court's resolution of 15 April 1996 concerning the validity of the referendum on the general granting of property rights to citizens, Journal of Laws 1996, no. 50, item 218).

5 Obwieszczenie Państwowej Komisji Wyborczej o skorygowanych wynikach głosowania i wyniku referendum konstytucyjnego, przeprowadzonego w dniu 25 maja 1997 r., Dziennik Ustaw 2003, nr 75, poz. 476. (The National Electoral Commission's announcement about the correcting of voting results and the result of the constitutional referendum held on 25 May 1997, Journal of Laws 2003, no. 75, item 476).

${ }^{6}$ Uchwała Sejmu Rzeczypospolitej Polskiej z dnia 17 kwietnia 2003 roku o zarządzeniu ogólnokrajowego referendum w sprawie wyrażenia zgody na ratyfikację Traktatu dotyczącego przystąpienia Rzeczypospolitej Polskiej do Unii Europejskiej, Dziennik Ustaw 2003, nr 66, poz. 613 (The resolution of the Republic of Poland's Sejm of 17 April 2003 on the ordering of a nationwide referendum on consent to ratify the Treaty concerning the Republic of Poland's entry into the European Union, Journal of Laws 2003, no. 66, item 613). The resolution also includes the calendar of measures connected with the conduct of the voting. 
European Union? The question worded in this way was voted for by 366 Deputies, with 16 against, and 22 abstaining 7 . Poland was among three countries, together with Slovakia and the Czech Republic, where the referendums were to last two days. This largely stemmed from fears about the attendance in the referendum and the wish to make it possible for as large a number as possible of those having the right to vote to participate in the referendum. It should be also emphasized that the voting result in the accession referendum in Poland was binding on the authorities. The threshold for the validity of the referendum was set very high. In Poland it was over $50 \%$ of the attendance of citizens having the right to vote. $58.85 \%$ of those having the right to vote participated in the referendum, of which $77.45 \%$ voted in favor of Poland's entry in the European Union while $22.55 \%$ were against. A comparatively high attendance and support for Poland's accession was reported in gminas [municipalities] with over a 100,000 inhabitants (attendance over 60\%, support for accession over $80 \%$ ). Generally, higher support for Poland's entry into the EU was expressed by town inhabitants ( $82.80 \%$ in town versus $65.76 \%$ in the countryside). Similarly, attendance in referendums in towns was higher as compared with attendance in the countryside (63.12\% in towns versus $51.22 \%$ in the countryside $)^{8}$. The highest support for Poland's entry into the European Union's structures was reported in the provinces in western and south-western Poland (Opole, Silesia, Western Pomerania, Lubulskie and Lower Silesia provinces). The lowest support for Poland's accession was reported in eastern Poland's provinces (first of all in the Podlasie and Lublin provinces).

\section{CONCLUSIONS}

To sum up, we should observe that the predominant majority of motions to hold a referendum were turned down because the parliamentary majority was insufficient to support them. We should note that the initiative concerning a referendum was most often taken by the entities identified with the opposition parties. The referendum on the passing of the new Constitution on 25 May 1997 had an effect on the introduction

${ }^{7}$ Figures given by the National Electoral Commission.

${ }^{8}$ Uchwała Sądu Najwyższego z dnia 16 lipca 2003 r. w przedmiocie ważności referendum ogólnokrajowego w sprawie wyrażenia zgody na ratyfikację Traktatu dotyczącego przystąpienia Rzeczypospolitej Polskiej do Unii Europejskiej, wyznaczonego na dzień 8 czerwca 2003 r., w którym głosowanie przeprowadzono w dniach 7 i 8 czerwca 2003 r., Sygn. Akt III SW 144/03 (The Supreme Court's resolution of 16 July 2003 regarding the validity of the nationwide referendum on consent to ratify the Treaty concerning the Republic of Poland's entry into the European Union, set for 8 June 2003, in which voting was held on 7 and 8 June 2003, File no. III SW 144/03); Obwieszczenie Państwowej Komisji Wyborczej z dnia 21 lipca 2003 r. o skorygowanym wyniku ogólnokrajowego referendum w sprawie wyrażenia zgody na ratyfikację Traktatu dotyczącego przystąpienia Rzeczypospolitej Polskiej do Unii Europejskiej (The National Electoral Commission's announcement of 21 July 2003 concerning the correction of the voting results in the nationwide referendum on consent to ratify the Treaty concerning the Republic of Poland's entry into the European Union). 
of new political-system solutions. It should be emphasized, however, that this was a mandatory referendum required for the adoption of the Constitution.

The situation changes completely in connection with the debate on Poland's accession to the European Union structures and the necessity for the citizens to express their opinion on this question in a referendum. Poland's entry into the EU was very important for the ruling elite. In contrast, there were vehement discussions provoked by the problem of holding a referendum on account of the need to ratify the Treaty Establishing a Constitution for Europe. Some of the debaters concluded that after the vote against the Treaty in France and the Netherlands, there was no need to hold a referendum in Poland.

Numerous controversies arise in connection with the problem of the validity of a referendum. It is a fact that the most important reason for the invalidity of a referendum is the failure to exceed the $30 \%$ threshold of attendance. In consequence, there are opinions demanding that the required threshold be reduced from $30 \%$ to $20 \%$ or abolished altogether. Others, for example representatives of local self-government authorities, who have a negative attitude towards the institution of the referendum to dismiss the decision-making organ, are rather in favor of raising the attendance threshold. Eugeniusz Zieliński writes about the lack of the political will to use the institution of the referendum on the part of politicians of all stripes [Zieliński, Bokszczanin, Zieliński 2003:250]. We have to do here, this author believes, with the nihilistic attitude of the ruling elites towards the value of the institution of direct democracy. They prefer to seek support in the more representative organs of State authority.

Some authors are optimistic about the possibility of stimulating society to action in the future. Others are pessimistic about the existing legal solutions in force and about the functioning practice.

\section{BIBLIOGRAPHY}

"Nie kradnij”. Nie powinno być referendum. Episkopat o uwłaszczeniu i reprywatyzacji, "Gazeta Wyborcza", 10.03.2000.

Frekwencja ponad 32 procent, 1996. "Rzeczpospolita", no 48.

Gebethner, S. 1997. Referendum konstytucyjne - uwiktania spoteczne i prawnoustrojowe, [in:] Referendum konstytucyjne w Polsce, ed. M. T. Staszewski, ISP PAN, Warszawa.

Grodzicki, R. 1987. Konsultacje spoteczne, "Nowe Drogi”, no 7.

Jabłoński, M. 1998. Wynik referendum a zasada dyskontynuacji prac Sejmu, "Przegląd Prawa i Administracji”, no 41.

Jabłoński, M. 2001. Referendum ogólnokrajowe w polskim prawie konstytucyjnym, Wydawnictwo Uniwersytetu Wrocławskiego, Wrocław .

Jaskiernia, J. 1987. Ustawowa regulacja konsultacji spotecznych i referendum, "Państwo i Prawo", no 7. Jaskiernia, J. 1995. Prawnoustrojowe i spoleczno-polityczne doświadczenia referendum z 29 listopada 1987 r., [in:] Referendum w Polsce współczesnej, eds D. Waniek, M. T. Staszewski, ISP PAN, Warszawa.

Kersten, K. 1990. Narodziny systemu władzy. Polska 1943-1948, Kantor Wydawniczy SAWW, Poznań. 
Konstytucja Rzeczypospolitej Polskiej z dnia 2 kwietnia 1997 r. wraz z indeksem rzeczowym, 2002. C. H. Beck, Warszawa.

Kruk, M. 1998. Transformacja polskiego porzadku konstytucyjnego w latach 1989-1997, [in:] Zasady podstawowej polskiej konstytucji, ed. W. Sokolewicz, Wydawnictwo Sejmowe, Warszawa.

Kuciński, J. 1989. Polskie referendum 29 listopada 1987 r., "Państwo i Prawo", no 2.

Malinowski A. 1996. Społeczne uwarunkowania referendum, [in:] Referendum w Polsce i Europie Wschodniej, eds M. T. Staszewski, D. Waniek, ISP PAN, Warszawa.

Marczak. T. 1986. Propaganda polityczna stronnictw przed referendum z 30 czerwca 1946 r., Wydawnictwo Uniwersytetu Wrocławskiego, Wrocław.

Marczewska-Rytko, M. 2001. Demokracja bezpośrednia w teorii i praktyce politycznej, Wydawnictwo UMCS, Lublin.

Mołdawa, T. 1996. Referendum w projektach konstytucyjnych lat 1989-1995, [in:] Referendum w Polsce i Europie Wschodniej, eds M. T. Staszewski, D. Waniek, ISP PAN, Warszawa.

Obwieszczenie Państwowej Komisji Wyborczej o skorygowanych wynikach głosowania i wyniku referendum konstytucyjnego, przeprowadzonego w dniu 25 maja 1997 r., Dziennik Ustaw 2003, nr 75, poz. 476.

Obwieszczenie Państwowej Komisji Wyborczej z dnia 21 lipca 2003 r. o skorygowanym wyniku ogólnokrajowego referendum w sprawie wyrażenia zgody na ratyfikację Traktatu dotyczącego przystąpienia Rzeczypospolitej Polskiej do Unii Europejskiej.

Paczkowski, A. 1995. Referendum z 30 czerwca 1946 r. Próba wstepnego bilansu, [in:] Referendum w Polsce współczesnej, eds D. Waniek, M. T. Staszewski, ISP PAN, Warszawa.

Paczkowski, A. 1999. Od sfatszowanego zwycięstwa do prawdziwej klęski. Szkice do portretu PRL, Wydawnictwo Literackie, Warszawa.

Projekty Konstytucji 1993-1997, 1997. Ed. M. Kallas, Wydawnictwo Sejmowe, Warszawa.

Referendum konstytucyjne w Polsce, 1997. Ed. M. T. Staszewski, ISP PAN Warszawa.

Referendum w Polsce wspótczesnej, 1995. Eds D. Waniek, M. T. Staszewski, ISP PAN, Warszawa.

Referendum z 30 czerwca 1946 r. Przebieg $i$ wyniki. Dokumenty do dziejów PRL, 1993. ed. A. Paczkowski, ISP PAN, Warszawa.

Staszewski, M. T. 1995. Referendum oprotestowane, [in:] Referendum w Polsce wspótczesnej, eds D. Waniek, M. T. Staszewski, ISP PAN, Warszawa.

Uchwała Sądu Najwyższego z dnia 15 kwietnia 1996 r. w sprawie ważności referendum o powszechnym uwłaszczeniu obywateli, Dziennik Ustaw 1996, nr 50, poz. 218.

Uchwała Sądu Najwyższego z dnia 16 lipca 2003 r. w przedmiocie ważności referendum ogólnokrajowego w sprawie wyrażenia zgody na ratyfikację Traktatu dotyczącego przystąpienia Rzeczypospolitej Polskiej do Unii Europejskiej, wyznaczonego na dzień 8 czerwca 2003 r., w którym głosowanie przeprowadzono w dniach 7 i 8 czerwca 2003 r., Sygn. Akt III SW 144/03.

Uchwała Sejmu Rzeczypospolitej Polskiej z dnia 17 kwietnia 2003 r. o zarządzeniu ogólnokrajowego referendum w sprawie wyrażenia zgody na ratyfikację Traktatu dotyczącego przystąpienia Rzeczypospolitej Polskiej do Unii Europejskiej, Dziennik Ustaw 2003, nr 66, poz. 613.

Ustawa konstytucyjna z dnia 17 października 1992 r. o wzajemnych stosunkach między władzą ustawodawczą i wykonawczą Rzeczypospolitej Polskiej oraz o samorządzie terytorialnym, Dziennik Ustaw 1992, nr 84, poz. 426.

Ustawa konstytucyjna z dnia 22 kwietnia 1994 r. o zmianie ustawy konstytucyjnej o trybie przygotowania i uchwalenia Konstytucji Rzeczypospolitej Polskiej, Dziennik Ustaw 1994, nr 61, poz. 251.

Ustawa konstytucyjna z dnia 23 kwietnia 1992 r. o trybie przygotowania i uchwalenia Konstytucji Rzeczypospolitej Polskiej, Dziennik Ustaw 1992, nr 67, poz. 336.

Ustawa z dnia 10 maja 2003 r. o zmianie ustawy o referendum ogólnokrajowym, Dziennik Ustaw 2003, nr 85, poz. 782 .

Ustawa z dnia 14 marca 2003 r. o referendum ogólnonarodowym, Dziennik Ustaw 2003, nr 57, poz. 507. Ustawa z dnia 27 kwietnia 1946 r. o głosowaniu ludowym, Dziennik Ustaw 1946, nr 15, poz. 104. 
Ustawa z dnia 28 kwietnia 1946 r. o przeprowadzeniu głosowania ludowego, Dziennik Ustaw 1946, nr 15, poz. 105 .

Ustawa z dnia 29 czerwca 1995 r. o referendum, Dziennik Ustaw 1995, nr 99, poz. 487.

Ustawa z dnia 6 maja 1987 r. O konsultacjach społecznych i referendum, Dziennik Ustaw 1987, nr 14, poz. 83.

Uziębło, P., Nowe regulacje prawne dotyczace referendum ogólnokrajowego w Polsce, http:// pedrou.w.interia.pl/referendum.htm (10.10.2012).

Winczorek, P. 2002. Projekt ustawy o referendach ogólnokrajowych, "Państwo i Prawo", no 12.

Zieliński, E., Bokszczanin, I., Zieliński, J. 2003. Referendum w państwach Europy, Wydawnictwo Uniwersytetu Warszawskiego, Instytut Nauk Politycznych, Warszawa.

\section{BIOGRAPHY}

Maria MARCZEWSKA-RYTKO, full Professor of political science and religious studies, President of the Research Committee on Political Socialization and Education (RC21) of the International Political Science Association (IPSA, 2012-2015); vice-Dean for Research and International Cooperation, Faculty of Political Science, UMCS (2008-2016). Her academic work involves problems of contemporary social and religious thought and political movements (especially direct democracy and populism). The author of five books in Polish: Populism. Problems of Theory and Political Practice in Latin America, Lublin 1992; Populism. Theory and Political Practice, Lublin 1995; Non-Christian Religions in Poland, Lublin 1997; Direct Democracy in Theory and Political Practice, Lublin 2001; Religion and Politics in Globalising World, Lublin 2010; editor of eight books in Polish connected with European integration, populism at the turn of the $20^{\text {th }}$ century, direct democracy; one in English: Religion in a Changing Europe. Between Pluralism and Fundamentalism. Selected Problems, Lublin 2003; coeditor of one of five volumes of Political Science Encyclopaedia, Warszawa 2011 and three collective books (in Polish). 